This item was submitted to Loughborough's Research Repository by the author.

Items in Figshare are protected by copyright, with all rights reserved, unless otherwise indicated.

\title{
Public engagement on aviation taxes in the United Kingdom
}

PLEASE CITE THE PUBLISHED VERSION

http://dx.doi.org/10.1080/15568310802471735

PUBLISHER

(c) Taylor \& Francis

VERSION

SMUR (Submitted Manuscript Under Review)

LICENCE

CC BY-NC-ND 4.0

REPOSITORY RECORD

Ryley, Tim, Lisa Davison, Abigail L. Bristow, and Alison Pridmore. 2019. "Public Engagement on Aviation Taxes in the United Kingdom". figshare. https://hdl.handle.net/2134/8211. 
This item was submitted to Loughborough's Institutional Repository (https://dspace.lboro.ac.uk/) by the author and is made available under the following Creative Commons Licence conditions.

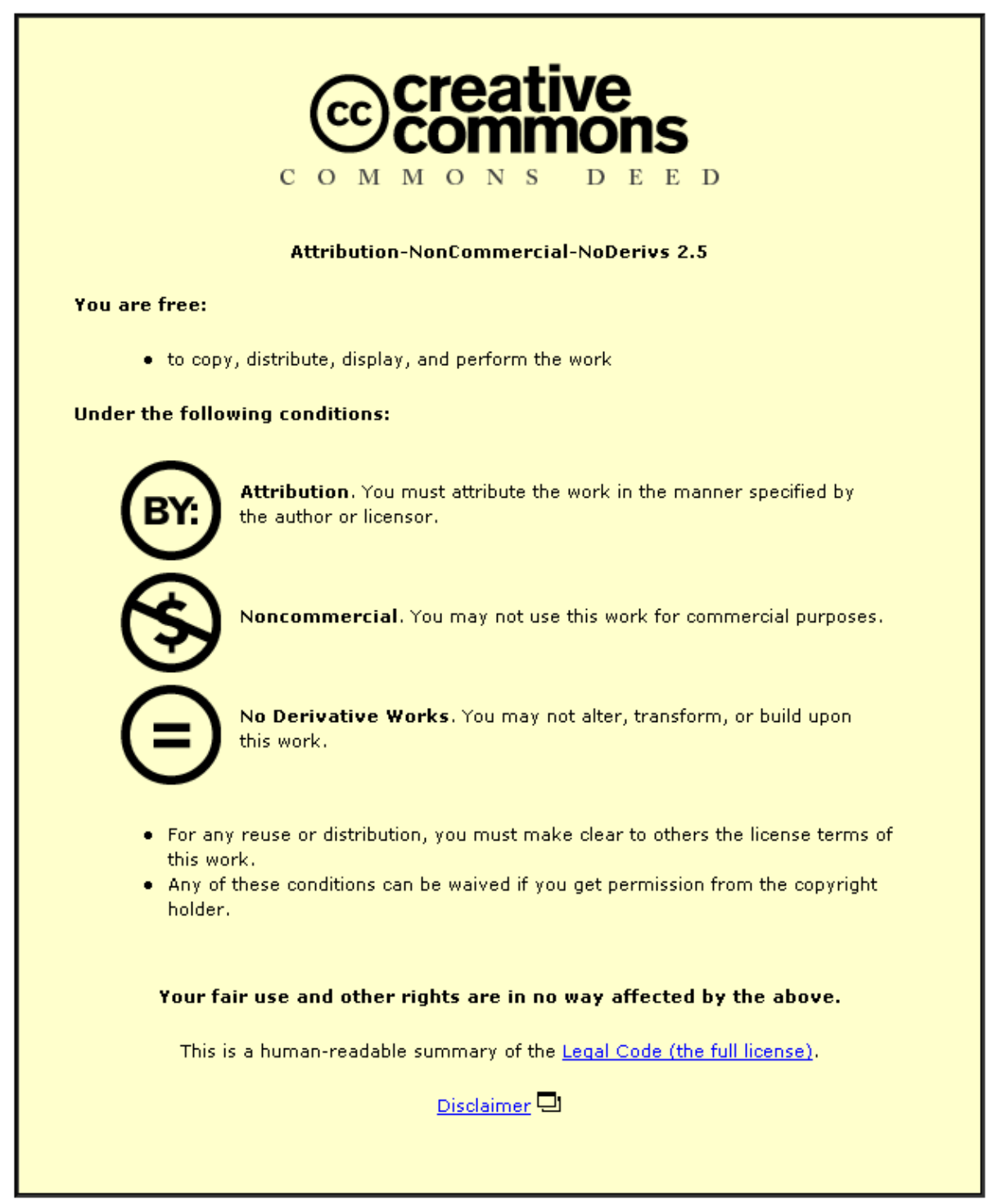

For the full text of this licence, please go to: http://creativecommons.org/licenses/by-nc-nd/2.5/ 
PUBLIC ENGAGEMENT ON AVIATION TAXES IN THE UNITED KINGDOM

Tim Ryley $^{1}$, Lisa Davison ${ }^{1}$, Abigail Bristow ${ }^{1}$ and Alison Pridmore ${ }^{2}$

${ }^{1}$ Transport Studies Group, Department of Civil and Building Engineering, Loughborough University, Leicestershire, LE11 3TU. United Kingdom

${ }^{2}$ AEA Energy and Environment, Central House, 14 Upper Woburn Place, London, WC1H 0JN

Tim Ryley e-mail: T.J.Ryley@lboro.ac.uk

Lisa Davison e-mail: L.J.Davison@lboro.ac.uk

Abigail Bristow e-mail: $\underline{\text { A.L.Bristow@lboro.ac.uk }}$

Alison Pridmore e-mail: alison.pridmore@aeat.co.uk

Dr Tim Ryley is the corresponding author:

Tel: +44 (0)1509 223422

Fax: +44(0)1509 223981 


\begin{abstract}
The acceptability of existing and potential future aviation taxes in the United Kingdom is explored using a focus group methodology. Focus group participants preferred an independently managed and accountable trust fund to use aviation tax for environmental improvements over the current Air Passenger Duty system. In terms of where additional aviation tax revenues should be spent, there was greatest support for improving United Kingdom surface transport and developing aircraft technology. Participants were tentatively supportive of the European Union Emission Trading Scheme, although would like to see companies within the scheme striving for maximum carbon reductions.
\end{abstract}

\title{
Keywords
}

Aviation, tax, public, environment. 


\section{Introduction}

This paper presents findings from a series of focus groups relating to current and future aviation taxes in the United Kingdom. The qualitative case study, at a national United Kingdom level, examines public engagement on aviation taxes. Taxes on aviation may be purely revenue raising or seek to internalise some of the external costs of aviation.

Air travel has increased five-fold in the United Kingdom over the past 30 years, and is predicted to rise from 200 million journeys in 2003 to around 400 million in 2020 and 500 million by 2030 (Department for Transport, 2003). The Department for Transport policy response involves the accommodation of growth through expansion at several United Kingdom airports; this includes three new runways (Stansted, Heathrow and Birmingham airports) and three new terminals (Exeter, Heathrow and Bristol airports).

Although growth in air travel has provided greater travel opportunities for individuals, there are challenges in ensuring that the development of aviation is more sustainable. The sustainability concept, key for all forms of transport since the Bruntland report (World Commission on Environment and Development, 1987), has been implemented at a United Kingdom level through the Sustainable Development Strategy (Department for Environment, Food and Rural Affairs, 2005). 
Research suggests that aviation makes an important contribution to the economy (York Aviation, 2004; Cooper and Smith, 2005). Airport expansion can be justified to support economic prosperity, but it is also acknowledged that the transport sector, including aviation, should meet its full environmental costs (Eddington, 2006). Emissions from aviation growth will result in the sector taking an increasingly significant proportion of any carbon budget (Anderson et al, 2007).

An international agreement, developed in Kyoto in December 1997, set a legally binding target for the United Kingdom to reduce greenhouse gas emissions, to $12.5 \%$ below 1990 levels by 2008-2012 (Department for Environment, Food and Rural Affairs, 2005). The United Kingdom is set to meet the Kyoto targets, partly due to manufacturing decline and changes in the energy sector 'dash for gas', ${ }^{1}$, but increases in road transport and aircraft emissions are of concern ${ }^{2}$. International aviation (along with shipping) is currently excluded from international agreements that set targets for cutting greenhouse gas emissions. This is due to the absence of an internationally agreed methodology for allocating these emissions at the national level. International aviation is also not included in United Kingdom domestic targets, such as the $60 \%$ reduction carbon emissions planned for 2050 (HM Government, 2007). The aviation sector's contribution to climate change is expected to increase substantially over coming decades. "Green taxes” are one

\footnotetext{
${ }^{1}$ Many UK energy companies built new gas power stations to reduce their demand for coal. Gas is seen as a cleaner and cheaper alternative to coal.

${ }^{2}$ Only domestic aviation emissions of $\mathrm{CO}_{2}$ are accounted for in the Kyoto Protocol.
} 
way of restraining demand (and emissions), and encouraging uptake of cleaner technology. For a discussion on the national aviation taxes applied across a range of countries, see Keen and Strand (2007), who also recognise that competition between nations regarding domestic airlines and airports and the tourism industry influence tax levels.

Government estimates suggest that the forecast growth in United Kingdom aviation will double carbon emissions from approximately 9 million tonnes of carbon (MtC) in 2000 to $17.4 \mathrm{MtC}$ in 2050 (Department for Transport, 2004). Other research suggests that carbon emissions from aviation in the United Kingdom could be much higher, for instance with a range of between 29.8 and 44.4 MtC in 2050 (Owen and Lee, 2006). Aviation produces other non-carbon emissions $^{3}$, which also impact upon on climate change, although the effects are less well understood and difficult to account for. To assist in the estimation of various activities (not just aviation) on climate, the concept of radiative forcing is utilised ${ }^{4}$.

The overall aim of the focus groups was to deepen understanding of the acceptability of existing and potential future aviation taxes.

\footnotetext{
${ }^{3}$ Non-carbon emissions include water vapour, which cause condensation trails (or contrails) and cirrus cloud at altitude; nitric oxide (NO) and nitrogen dioxide (NO2), together called NOx, which can form ozone; soot and sulphate particles, known as particulates; methane; and sulphur oxides, carbon monoxide, hydrocarbons and radicals like hydroxyl.

${ }^{4}$ A radiative balance exists between absorption and reflection of solar energy. Where a human activity (or an activity without human involvement) alters greenhouse gases or particles this activity results in a radiative imbalance. This imbalance cannot be maintained for long and the climate system adjusts to restore the radiative balance. The global, annual, average radiative imbalance caused by human activity is radiative forcing. The EC TRADE OFF project estimated that aviation's radiative forcing was approximately twice that of carbon dioxide alone, excluding cirrus cloud enhancement (Department for Transport, 2006).
} 
In terms of existing aviation taxes (as of March 2007, the month of the focus groups), air travel is subject to Air Passenger Duty (APD), introduced in 1994 and payable per passenger per flight on departure from United Kingdom airports at standard amounts differentiated by distance and class (HM Customs \& Excise, 2003). APD is currently, in the lowest class of travel, $£ 10$ for most European destinations and $£ 40$ for further afield; the levels were doubled from $1^{\text {st }}$ February 2007, announced in the Pre-Budget Report (HM Customs \& Excise, 2006).

The European Union Emission Trading Scheme (EU ETS) was introduced in January 2005 as a key mechanism to reduce green house gas emissions. Companies within the EU ETS may either reduce their emissions below the 'cap' set and sell permits, or emit above the cap and purchase additional permits. Companies will choose to do whatever is cheapest and emissions are reduced, therefore, where it is easiest and cheapest to do so first. Currently this includes emissions of carbon dioxide from electricity generation and the main energy intensive industries. Overall, these account for around $50 \%$ of United Kingdom carbon dioxide emissions. The European Commission has proposed legislation to include aviation in EU ETS, and this would occur in two stages. From the start of 2011, emissions from domestic and international flights between EU airports would be covered, and from the start of 2012 the scheme would cover emissions from all international flights, that arrive or depart from an EU airport. 
Keen and Strand (2007), considering the international nature of environmental pollution from aviation, support the global introduction of an indirect tax upon air travel. It is their view that the optimum form would consist of a fuel or emission tax to consider cross-border emissions and ticket tax, ideally in the form of VAT, to raise revenue; this is seen as a far more sophisticated tool than blunt flat fare ticket taxes. Given the limitation upon fuel taxation presented by the Chicago Convention, designed to develop civil aviation, Keen and Strand are supportive of the EU ETS as a mechanism to internalise environmental costs.

The Stern Review (Stern et al, 2006), commissioned by the United Kingdom Government, calls for the aviation industry and air passengers to cover the external costs of air travel in terms of the cost of climate change ${ }^{5}$. The Stern Review identifies the growing contribution air travel is making to greenhouse gas emissions, and supports using market forces to regulate these. The report recognises that there is potential for efficiency gains within the aviation industry, through improved air transport management and aircraft design, but at present there is no prospect of technology switching (although biofuels, and possibly some hydrogen or electric vehicles could have some impact for surface transport, technology breakthroughs are unlikely in the aviation sector). There is ongoing research exploring the feasibility of synthetic fuels, biofuels

\footnotetext{
${ }^{5}$ Although politically influential, the Stern Review has led to a range of detailed critiques. Examples include Dasgupta (2007), which criticises the assumed parameter values and model specification, and Tol (2006), which states that the review is too politically influenced and based on 'pessimistic' literature, thus affecting the scale of results.
} 
and hydrogen as an alternative to kerosene, though at present there are practical, technological, safety and infrastructure constraints for each alternative; therefore greater benefit is achieved by improving airframe and engine design and through operational savings, e.g. improved air traffic management (Bows et. al., 2006, Royal Commission on Environmental Pollution, 2002).

Cairns and Newson (2006) suggest that support for making air travel more expensive on environmental grounds has grown over time. Their suggestions for restraining air travel demand include an increase in APD levied by the United Kingdom Government on passenger trips from United Kingdom airports (as shown previously, APD levels rose in February 2007), and the addition of VAT to domestic air tickets (also suggested by the House of Commons Environmental Audit Committee in August 2006). Other options might include fuel tax, and a more radical solution would be to develop personal carbon allowances. Attitudinal work by Ipsos MORI (2007) has also detected a gradual shift in public opinion towards making flying more expensive to reflect the environmental damage. However, individuals surveyed are only willing to pay such a tax if they have evidence that the revenue raised will be spent on measures to reduce the impact of aviation on climate change.

Mayor and Tol (2007) model domestic and international tourist flows to estimate the impact of the APD changes. They find that the recent rise in APD 
levels has a small but perverse effect. This is because, Mayor and Tol argue, tourist destination choice is driven by relative prices, a boarding tax makes farflung destinations more appealing, not less, and UK aviation emissions increase as a result, albeit by only a fraction.

In the absence of environmental taxes on aviation, businesses and individuals can offset their emissions through a number of different offsetting companies (for a useful summary see Department for Environment, Food and Rural Affairs, 2007). Carbon offsetting involves voluntary payments to projects which will prevent or remove the equivalent amount of carbon (or carbon equivalent) emitted by a flight or other activity, as calculated by the companies. Such systems are provided both by third-party sources (e.g. http://www.climatecare.org, accessed 21-02-2008) and by airlines (such as British Airways and easyJet).

During the time frame of the focus groups, March 2007, the subject of aviation taxes was high on the policy agenda. This was partly due to the development of green policies by the two main political parties. In mid-March, the Conservative party produced a Consultation document on the use of environmental taxes to reduce carbon emissions from aviation (The Conservative Party, 2007); these proposals include fuel tax on domestic flights and a frequent flyer tax. The United Kingdom Government also put forward for consultation a draft Climate Change Bill (HM Government, 2007), which proposes binding carbon dioxide targets. 


\section{A focus group approach}

Focus groups are a qualitative research method, defined as "a group of individuals selected and assembled by researchers to discuss and comment on, from personal experience, the topic that is the subject of the research" (Powell et al, 1996, p199). They provide a forum for participants to share their attitudes, feelings and beliefs and perhaps reach a consensus on a topic. Evidence show that a preferable focus group size involves 6-8 participants plus the moderator(s), although they can work successfully with between four and 15 people (Gibbs, 1997).

Designed to imitate everyday group discussion, focus groups provide researchers with "the opportunity to observe a large amount of interaction on a topic in a limited period of time” (p 8, Morgan, 1997a). It is accepted that participants will have set and malleable opinions, some of which will develop and shift during the focus group process (Litosseliti, 2003). The opportunity to see how this occurs is a strength of the method. However, group dynamics influence results; there is likely to be tendency towards conformity and perhaps also polarisation, where more extreme views are expressed in a group setting. Both of these factors can make it difficult to distinguish between the individual and group view. 
Furthermore, focus groups are not in a naturalistic social setting; findings need to be considered in context. Results will be influenced by the presence of the moderator, their position and the extent to which the discussion is guided, though, arguably this would be greater in individual interviews (Morgan, 1997a). While focus groups can encourage participants to censure what they say, the method also provides an environment which encourages individuals to disclose information. With few exceptions (e.g. observation), methods which assess individual (or group) attitude and behaviour, both quantitative and qualitative, are subject to the limitation of how this transfers into 'real life' action.

During March 2007, an independent sample of participants was recruited onstreet from people in the centre of Loughborough, Leicestershire. Loughborough is small university town of around 60,000 located in the East Midlands region of England ${ }^{6}$; due to the presence of Loughborough University within the town, it has a higher than average proportion of students within the population. East Midlands airport, regional in focus, is the nearest airport to Loughborough; the distance is approximately 10 miles (16 kilometres).

With the intention of having between six and eight people at each of the four focus groups, 40 people were recruited in total across the four focus groups. A financial incentive was provided to each individual participating. Individuals

\footnotetext{
${ }^{6}$ Mid-2004 Population Estimate for Leicestershire and Districts show Loughborough to have a population of 57,560 in 2004, http://www.leics.gov.uk/index/your_council/about_leicestershire/statistics/research_info_popul ation.htm, accessed 21.02.2008
} 
passing recruiters were invited to participate in one of four pre-scheduled focus groups the following week.

Recruitment quotas were set of no more than three students invited to each focus group, and at least three of each sex. These quotas were set in discussion with the client to ensure a sample as representative of the local population as possible within the focus groups. Naturally, such a small sample cannot be representative of the United Kingdom population, a drawback of focus groups.

Focus groups should be located as close to the focus group participants as possible to allow easy access; suitable accommodation should allow for taping of the focus group, and so should be quiet and free from interruption (Morgan, 1997b; Krueger and Casey, 2000). To enable this, the focus groups were held in a hotel close to the central Loughborough recruitment area.

Each focus group included a moderator and assistant moderator. A moderator facilitates the group, making sure everyone is involved and introducing the topics of discussion. There was also a short, standardised questionnaire survey within each focus group, to gain information on respondent attitudes to the environment, measures to reduce aviation emissions, and their likely behavioural response to price signals. The questionnaire data provides quantitative information to supplement the qualitative focus group data, and proved a useful validation tool. It also differentiates between the individual and group view. 
The aim of the research was to ascertain the acceptability of current and potential future aviation taxes. To enable this, the following topic guide was developed:

1. Introduction - their air travel

2. Environmental issues associated with aviation

3. Attitudes towards existing aviation taxes

4. Use of additional revenue from aviation taxes

5. Future aviation taxes and other measures

To assist with the analysis, the questions were semi-structured according to themes. For concepts that may be difficult for individuals to grasp (APD and EU Emissions Trading Scheme), time was provided for participants to explore these issues, before they were provided with a sheet summarising the measure. In addition to APD and the EU Emissions Trading Scheme, the following options were also considered in the project: VAT on flight tickets, fuel duty payable on aviation fuel, individual carbon rationing, and frequent flyer taxes. Direct payment for carbon offsets was not considered to be within the scope of the focus groups as it is not a form of tax. However, use of aviation tax, to invest in measures to offset the carbon created by air travel is considered in the discussion. 
It was also hoped that the focus groups would create an environment that encouraged open discussion, thus generating a range of other ideas. Some ideas suggested by the focus groups may not be feasible, but other more interesting ideas might assist the debate on improvements to the aviation tax system.

\section{Composition of the focus groups}

There were 27 focus group participants; the numbers split according to each focus group, and by sex (total of 13 male, 14 female) are:

- $\quad$ Focus Group 1: 6 (2 male, 4 female)

- $\quad$ Focus Group 2: 8 (3 male, 5 female)

- $\quad$ Focus Group 3: 7 (5 male, 2 female)

- $\quad$ Focus Group 4: 6 (3 male, 3 female)

All groups, therefore, had the preferred size of between 6 and 8 participants.

Table 1 shows the age and status of all focus group participants. Although fairly representative of the population, the composition of the focus groups is younger than the population of Loughborough and the United Kingdom as a whole. This may relate to younger people being more willing to participate in focus groups (perhaps more attracted by the payment). This in turn may bias the results; the younger generation may be more aware of the environmental 
issues associated with aviation. Of the 27 participants, 23 lived in the town of Loughborough, the remainder in the surrounding villages.

All of the focus group participants had flown before (from the ice-breaker question). Most (20) had flown the previous year, as shown by the questionnaire; three of these could be considered frequent flyers (flown at least four times the previous year). Most flights undertaken by participants the previous year had been for leisure purposes; only three participants had flown for business purposes (two had made one business trip, and one at least five business trips).

\section{Focus group analysis}

The analysis has been undertaken systematically according to the focus group themes; data has been used from the focus groups and the questionnaires. As argued by Bloor (2001), in academic social research a full transcript of each focus group is essential to avoid losing valuable detail, richness, and rigour in

analysis. A word-for-word transcription of each focus group was undertaken; direct focus group quotations have been incorporated into the analysis to illustrate the findings.

\subsection{Environmental issues associated with aviation}


An initial question covered benefits and problems associated with aviation, as perceived by the participants. Benefits included the convenience and speed of air travel and the opportunity for new travel destinations. The responses did not concern environmental issues, rather personal inconvenience at airports (especially security) and uncomfortable seating on aeroplanes. In terms of sector contributions to the emissions of greenhouse gases, the second and third focus groups were in agreement about heavy industry making the largest contribution to climate change; the other two focus groups were less sure.

\subsection{Attitudes towards existing aviation taxes}

There was much confusion and a lack of understanding about the nature of the existing aviation tax system. Some of this confusion related to United Kingdom Government messages: they are “encouraging more personal air travel and then trying to stop this flying” (focus group 2). There was general frustration across focus groups that airlines attract you with a low price and only then add tax to the cost; it is particularly difficult when having to pay for multiple flights (e.g. when travelling with children). All of the focus groups wanted transparency in the tax system, value for money, and were critical of the United Kingdom Government. This was particularly the case for focus group 2.

The European Commission have since responded to the "misleading advertising and unfair practices on airline ticket selling websites” (European 
Commission, 2007) and have demanded that airlines provide transparent information on pricing, availability and contract terms or face legal action. The United Kingdom Office of Fair Trading took action against thirteen airlines for not including "all fixed, non-optional costs, such as taxes, in prices on their websites” (Office of Fair Trading, 2007).

In terms of improvements, focus group 4 reckoned that more bands could be added to the current APD structure to incorporate distance. Focus group 1 thought that air freight companies should pay for their emissions.

"Why not trial some new freight charges and check the air freight as they are carrying a heavy load and some take 30 to 40 tons out a night, no offence, but they should pay more as they do for fuel as they are in and out all night using the airport.” (Focus group 1)

The idea of a Trust Fund was proposed in two of the focus groups. The general public could decide, say through an election, where the aviation tax goes to; the fund would have independent (i.e. not political) management.

\subsection{Use of additional revenue from aviation taxes}

The focus groups and questionnaires examined the acceptability of measures to reduce aviation emissions, and the use of aviation tax to offset global emissions. Offsets were included because the aviation industry is not a closed 
system in terms of environmental damage and resource use. Whilst it is not fiscal policy to earmark taxes, the visibility, for example, of road tax funding transport infrastructure (referred to in focus group 3) increases acceptability; this can be contrasted with APD, viewed by many within the focus groups as unacceptable its current form.

From the questionnaire, the three most popular responses (in order) to 'Where should any additional money raised from increased aviation tax go?’ were: ‘Green’ energy (e.g. wind farms, solar panels, energy efficient light bulbs), improving aircraft and aviation technology, and investment in United Kingdom transport infrastructure. All of the responses are shown in Table 2.

A further question had more of an emphasis on measures to reduce carbon emissions from aircraft. The most popular response to measures was to ‘improve aircraft efficiency'; all participants were supportive of this measure. A full list of responses to the measures is shown in Figure 1.

\subsubsection{Long-term carbon reduction measures}

Long-term carbon reduction measures to reduce the environmental impacts of aircraft, either in the United Kingdom or abroad, were discussed within the focus groups. Such projects included improving aircraft and aviation technology and design, aviation research, and investment in United Kingdom transport infrastructure (must be United Kingdom based). 
"I think I like the engineering aspects of the fuel development of other forms of energy like hydrogen. I know this isn’t going to be very helpful in the short term but in the long term if somebody can come up with a breakthrough that could potentially change a lot. Obviously that's the long term because people are still sceptical if they can do it.” (Focus group 4)

Across all focus groups United Kingdom surface transport came up as an issue. The United Kingdom railway system was remarked as the "worst in Europe for being on time and cleanliness" (focus group 2); contrasting with good examples in mainland Europe and Japan. Improvements to the railway system included making rail pricing more competitive with air fares and developing a high speed rail system.

The third focus group had an emphasis on the role of aviation research and improving aircraft technology. There was a feeling that "something should be done”, and that "if there is a solution for cars, there should be for planes”. As an associated measure, the first and third focus groups put forward improvements in aircraft capacity. They proposed that flights be combined to ensure aeroplanes fly with a higher capacity and less fuel waste; perhaps airlines should meet an occupancy rate before flying (although it was acknowledged that airlines need to keep to their designated timetable). 
“But I think running flights half empty, you've got to sort of question it really, is it really worth doing it and I think airlines like Ryanair and easyJet are good in the sense they get the load up on the aircraft and if they recognise that the routes not working then they take it away but they're the ones that contribute to a massive growth in air travel cause we all want to get away for $£ 5$ return.” (Focus group 3)

\subsubsection{Short-term carbon reduction measures to offset environmental impacts}

A number of carbon reduction projects (short-term) to offset the environmental impacts of aircraft, either in the United Kingdom or abroad, were presented to participants: planting trees, improving degraded areas, and 'green’ energy (e.g. wind farms, solar panels, energy efficient light bulbs). There was general agreement in favour of these measures, particularly the 'green' energy measures. Often when 'green' energy is mentioned, participants would like more wind turbines, but recognise people tend to complain about them because of visual pollution. Help for households to implement green energy (e.g. solar panels), both in terms of awareness and financial assistance, was stressed in one of the focus groups.

\subsubsection{Other short-term carbon reduction measures}


The first focus group had more of an emphasis on the moral implications of climate change, and the impact upon developing countries. This focus group also seemed to have the most 'green' participants. Money from aviation tax should be put towards relieving poverty in developing countries as well as alleviating climate change impacts, although it was acknowledged that corruption is a problem in the developing world. Developing countries were also mentioned in passing during two other focus groups.

The role of video-conferencing, to reduce travel, was discussed in focus group 3. Although this saves money for businesses and reduces emission, they recognised that face-to-face contact is often necessary to develop business relationships.

Educating the general public about climate change was considered to be very important in several focus groups. A particular stress was placed on junior school education in focus group 1 , but at other times educating and informing the entire population about the climate change impacts was mentioned, for the United Kingdom and to other (particularly developing) countries.

There are some short-term carbon reduction measures that were not generated from focus group discussions, such as reducing airport congestion, determining shorter flight routes, improving aircraft taxying, and ensuring a smooth landing of aircraft. This lack of awareness amongst participants suggests that the 
general public need to be better informed of these aviation industry related carbon reduction measures.

\subsection{Future aviation taxes and other measures}

\subsubsection{European Union Emission Trading Scheme (EU ETS)}

This analysis section explores possible future aviation taxes and other, associated measures, starting with the European Union Emission Trading Scheme (EU ETS). At least one individual within each focus group had heard of EU ETS, although the numbers were always in the minority, and there was little understanding of the concepts involved. In response to the EU ETS summary sheet, participants were tentatively supportive of the scheme. Focus group 1 agreed that it worked on the surface, although it would depend on the level set (they also commented that the USA is the worst polluter and not in the scheme). Within focus group 2, there was a consensus that companies would not take the initial step to improve their emissions and so the only way would be to compel them through government intervention (e.g. via the EU ETS).

Focus groups 3 and 4 felt that EU ETS should encourage companies further to aim as low as possible in their carbon emissions. Rather than setting a percentage cap, higher expectations should be encouraged with tax breaks to companies who exceed their targets by the most. In focus group 4 it was suggested that companies over the target should be penalised, but that those 
under the target should not be rewarded; also, if the cap is reduced larger companies will have more power to buy permits and so smaller companies might suffer. In the EU ETS, companies who miss the target are penalised; they have to buy permits and those who perform competently, sell. Therefore, in a 'good' emissions market the incentives are already in place.

"Anything that gets the emissions down sounds good to me but rather than settling a percentage figure that they have to achieve like $10 \%$, which is very small, we should be striving for the absolute maximum that you can go for and the more percentage that a company can reduce the $\mathrm{CO}_{2}$ the more tax breaks you'll get. I suppose it seems silly to me to set like a percent reduction you can easily do that but there’s no incentive to push the boundary even further.” (Focus group 3)

Most focus groups reflected on the international aspects of aviation growth and improving co-operation between countries. Many of the countries with large emissions were mentioned (e.g. the USA, China and India in focus group 3). Focus group 1 stated the difficulty to achieve a consensus between the United Kingdom and the USA, and to monitor emissions. Two other focus groups felt that the United Kingdom should lead by example and promote the EU ETS, without being discouraged that other countries are not promoting climate change policies.

\subsubsection{Aviation tax developments}


On the suggestion that aviation fuel should be taxed (difficult with legally binding bilateral agreements but many are being renegotiated), focus group 1 thought it would make sense to link tax to fuel, ensuring any tax would be proportional to flight costs rather than as a flat rate. In a similar vein, focus group 4 considered that fuel duty proportional by distance, or VAT, should be considered.

"Either a tax charged to the airline for passenger miles flown, or a percentage of the ticket cost with a minimum charge for low-cost airlines” (Focus group 4 Questionnaire)

A variety of opinions were provided on the proposal to relate aviation tax to the frequency of flying (e.g. the Conservative Party proposal that passengers pay more if they fly more than once a year - see The Conservative Party, 2007 published before the focus groups were undertaken). Focus group 1 was of the view that people who fly more often should be taxed more, with a differential to allow people to still go on holiday. Focus group 2 was against the frequent flyer proposal because you cannot tax people for being successful. The frequency of flying was also rejected as a proposal on the grounds that people who fly more are taxed more anyway (focus groups $1 \& 3$ ). Conversely, some in focus group 4 backed the frequent flyer proposal, but only for those who have holiday homes or 'fly too frequently'. 
The role of lifestyle choices across sectors (e.g. trade-off air travel against energy consumption), and the associated concept of rationing personal air travel, were proposed by the moderator during the focus groups. Focus group 1 stated that this is an EU ETS scheme at a lower, individual level.

"Perhaps we could think of people having a bank of carbon credits and spending them could effect our lifestyle and how people can fly. When they have used them up, perhaps they can buy them off someone else. Living on individual terms doesn’t always work, but at least the carbon emission output is more controlled.” (Focus group 1)

Focus groups 3 and 4 were cynical about the practicalities of this proposal, that there would be difficulty in administering and policing the system ("people would fiddle the system”). An individual within focus group 4 stated that rationing flights would be fine for most people but not for businesses.

A suggestion from focus group 3 was to charge a higher aviation tax if there is a surface transport alternative; this would be the case for United Kingdom flights and also for certain mainland European destinations such as Paris and Brussels.

"Personally I think there should be a higher tax for flights where you could easily take a train, so if you had a higher rate of tax, lets say if you were coming out of Heathrow for example, you'd have a high rate 
of tax on flights to Manchester, Glasgow, Edinburgh, down the south coast, but even across to Paris and even across to Brussels because you could take the Eurostar and it's far more kind” (Focus group 3)

\subsubsection{The role of 'greener' airlines}

During the consideration of the choice of a 'greener' airline, all focus groups at some point stressed a tendency to go for price when booking airline tickets. This would continue unless some airlines become particularly green (focus group 1); it was also felt that airlines should do more, not just passengers (focus group 1). Focus group 3 reckoned there would be no way to police this measure. The Virgin Atlantic trial measure of towing aircraft to the runway in

order to save fuel was mentioned (focus groups $3 \& 4$ ); the prize on offer by Richard Branson (Chief Executive of Virgin Atlantic) for measures to alleviate climate change was mentioned in focus group 4.

\subsubsection{Assisting participants in their air travel choices}

A variety of measures to assist the general public in their air travel choices were discussed (e.g. better information on carbon emissions, labelling on tickets \& emissions per passenger data). Such measures were linked to education by the first focus group. Focus group 3 thought that it depends how the measures were advertised - they would need to be in laymen's terms not 
jargon. Focus group 4 had a desire to know the efficiency of a flight, not available at the moment.

\author{
"When I use the Council tip for rubbish, percentages are being quoted \\ and you can see the effects. I think of recycling and this is well \\ publicised.” (Focus group 1)
}

\begin{abstract}
An interesting idea coming from Focus Group 4 was that of a league table of airlines incorporating carbon emissions, to enable choice by cost and environmental credentials. An energy efficiency rating could be applied similar to that for white goods in the United Kingdom. Air companies would need to be encouraged to use the league tables for their advantage - to be seen to do the right thing.
\end{abstract}

\begin{abstract}
"League tables, so you could choose by cost and my environmental credentials ... you know you should be going with the green one but you can see which one is the most expensive, which is the greener and perhaps a happy medium.” (Focus group 4)
\end{abstract}

\title{
5. Discussion and conclusions
}

The research presented in this paper has deepened understanding of the acceptability of existing and potential future aviation taxes, contributing to the increasingly active debate in this area. The focus group participants were 
confused about the nature of the existing aviation tax system and the environmental impacts of aviation. There is, therefore, a need to engage, inform and educate the general public about climate change and the environmental impacts of aviation. Perhaps there is a need to encourage individuals to be more responsible for their actions and to feel they are participating in the process. All of the focus groups wanted the aviation tax system to be transparent and independently managed (i.e. free from political interference), suggesting a lack of public trust in Government. For a 'green' tax to be acceptable, it would need to be transparent to the general public.

There was greatest support for the long-term measures to improve United Kingdom surface transport and aircraft technology. Short-term 'green energy' carbon offset measures, such as wind farms and solar panels, were also popular amongst participants. Much of the response indicates that participants would rather other stakeholders act, such as policy-makers or the aviation industry, than take on the responsibility themselves. The lack of awareness of some aviation industry measures to reduce carbon emissions, such as improving the taxying and landing of aircraft, demonstrates a need to better inform the general public regarding these aspects.

In the exploration of future developments of the aviation tax system, participants were tentatively supportive of the European Union Emission Trading Scheme (EU ETS) and felt that the United Kingdom should lead by example for climate change solutions. However, participants would like 
companies within the EU ETS to strive for the maximum viable reductions in carbon. Although the focus has been on a national United Kingdom aviation tax system, due to the international nature of aviation there needs to be agreement and policy instrument developments at a broader scale, such as through the EU ETS.

There were two interesting, unprompted proposals generated from the focus groups that could be developed further in the debate on improvements to the aviation tax system. The first is to extend taxation to cover freight operations; this could be a per flight tax based on emissions for freight carriers, perhaps adjusted for the weight carried The second is to develop a league table of airlines that would incorporate carbon emissions as well as flight costs for a particular journey. Although some airlines already do this in practice, an objective classification would be more useful than self-promotion from airlines.

There were two further unprompted proposals that, although interesting, are less feasible. Some focus group participants recommended a higher band of aviation tax for passengers if a viable surface transport alternative is available (e.g. within the United Kingdom or some mainly Europe destinations). However, preferential taxation on the availability of alternatives creates externalities. A further focus group proposal was an improvement in aircraft occupancy to reduce emission levels per passenger; one possibility would be to impose minimum capacity levels at which an aircraft should fly (although 
airlines would probably then offer low-fare tickets to fill their aircraft, thus stimulating demand).

This study has investigated individual responses in the form of attitudes with respect to the acceptability of aviation taxes. Despite an apparent willingness amongst the general public to make flying more expensive on environmental grounds (Ipsos MORI, 2007), albeit that the revenue is spent to reduce the impact of aviation on climate change, there is recent evidence from a UK study on developing a framework for pro-environmental behaviour (Department for Environment, Food and Rural Affairs, 2008) that many individuals have a low willingness to act or become engaged in the environmental debate (28\% of the UK population are categorised as either "Stalled starters" or "Honestly disengaged"). A recent air travel survey, of 503 respondents, has shown that almost half (44\%) of respondents agreed with the statement that "the UK media tends to overstate the effects of climate change” (Ryley and Davison, 2008). This figure represents an increase from a similar survey conducted the year previously; perhaps people are becoming more cynical to the messages they are receiving concerning climate change and air travel. Certainly, as shown by the emphasis on transparency within the focus groups, the way in which environmental messages are sold to the general public through political and media channels is of paramount importance to the public acceptability of environmental measures such as aviation tax.

\section{Acknowledgements}


The authors would like to thank the Sustainable Development Commission for the funding which enabled the focus groups to be undertaken. This paper develops upon the project report, written in May 2007, and available on the Sustainable Development Commission website (Ryley et al, 2007). Any views expressed in the paper are those of the authors alone. We would also like to thank George Raymond, Ann Cluskey, Joe Kendal and Stuart Meek at Loughborough University in the recruiting of focus group participants and the transcribing of the focus group data.

\section{References}

Anderson K, Bows A, Footitt A. 2007. Aviation in a low carbon EU. A research report by the Tyndall Centre, University of Manchester. Friends of the Earth.

[http://www.foe.co.uk/resource/reports/aviation_tyndall_07_main.pdf, accessed 21-02-2008].

Bloor M. 2001. Focus groups in social research. London: Sage.

Bows, A., Anderson, K., Upham, P., 2006. Contraction convergence: UK carbon emissions and the implications for UK air traffic. Tyndall Centre for Climate Change Research Technical Report 40. 
[http://www.tyndall.ac.uk/research/theme2/final_reports/t3_23.pdf, accessed 21-02-2008]

Cairns S, Newson C. 2006. Predict and decide. Aviation, climate change and United Kingdom policy. Environmental Change Institute, September 2006. [http://www.eci.ox.ac.uk/research/energy/predictanddecide.php, accessed 2102-08]

The Conservative Party. 2007. Greener skies: A consultation on the environmental taxation of aviation

[http://www.conservatives.com/pdf/greenerskiesconsultation.pdf, accessed 2102-2008]

Cooper A, Smith P. 2005. The Economic Catalytic Effects of Air Transport in Europe.

[http://www.eurocontrol.int/eec/gallery/content/public/documents/EEC_SEE_r eports/EEC_SEE_2005_004.pdf, accessed 21-02-2008]

Dasgupta P. 2007. Comments on the Stern Review's Economics of Climate Change, National Institute Economic Review 199 (4) : 4-7, January 2007 [http://ner.sagepub.com/cgi/reprint/199/1/4-a, accessed 21-08-08]

Department for Environment, Food and Rural Affairs. 2005. Securing the Future - United Kingdom Government sustainable development strategy. 
London: HMSO. [http://www.sustainable-development.gov.uk/publications/ukstrategy/index.htm, accessed 21-02-2008]

Department for Environment, Food and Rural Affairs. 2007. Climate Change: Carbon Offsetting [a website summary, http://www.defra.gov.uk/environment/climatechange/uk/carbonoffset/index.ht m, accessed 21-02-2008]

Department for Environment, Food and Rural Affairs. 2008. A framework for pro-environmental behaviours. London: HMSO.

[http://www.defra.gov.uk/evidence/social/behaviour/pdf/behaviours-jan08report.pdf, accessed 21-02-2008]

Department for Transport. 2003. The Future of Air Transport. Air Transport White Paper. London: HMSO.

[http://www.dft.gov.uk/about/strategy/whitepapers/air/, accessed 21-02-2008].

Department for Transport. 2004. Aviation and Global Warming. Department for Transport. London: HMSO.

[http://www.dft.gov.uk/about/strategy/whitepapers/air/docs/, accessed 21-022008].

Department for Transport. 2006. Air Transport White Paper Progress Report. London: HMSO. 
[http://www.dft.gov.uk/about/strategy/whitepapers/air/aviationprogressreportse ction/aviationprogressreport, accessed 21-02-2008].

Eddington R. 2006. The Eddington Transport Study: The case for action, Sir Rod Eddington’s advice to Government. London: HMSO.

[http://www.dft.gov.uk/about/strategy/transportstrategy/eddingtonstudy/, accessed 21-02-2008].

European Commission (2007) EU crackdown on misleading airline ticket websites. Press release 14-11-2007.

[http://ec.europa.eu/cyprus/news/latest_news/consumers_14112007_en.htm, accessed 21-02-2008].

Gibbs A. 1997. Social Research Update, 19: Focus Groups. University of Surrey. [http://sru.soc.surrey.ac.uk/SRU19.html, accessed 21-02-2008]

HM Custom and Excise. 2003. Notice 550 Air Passenger Duty. [http://customs.hmrc.gov.uk/channelsPortalWebApp/channelsPortalWebApp.p ortal?_nfpb=true\&_pageLabel=pageExcise_InfoGuides\&propertyType=docum ent\&id=HMCE_CL_000505\#downloadopt, accessed 21-02-2008]

HM Custom and Excise. 2006. Pre-budget report notes.

[http://www.hmrc.gov.uk/pbr2006/pbrn-all.pdf, accessed 21-02-2008] 
HM Government. 2007. Draft Climate Change Bill.

[http://www.official-documents.gov.uk/document/cm70/7040/7040.asp, accessed 21-02-2008]

Ipsos MORI. 2007. Attitudes to aviation and climate change. Report for the Commission for Integrated Transport, February 2007.

[http://www.cfit.gov.uk/docs/2007/climatechange/index.htm, accessed 21-022008].

Keen M, Strand J. 2007. Indirect taxes on international aviation, Fiscal Studies 28 (1): 1-41.

Krueger RA, Casey MA. 2000. Focus groups: a practical guide for applied research. 3rd edition. London: Sage.

Litosseliti, L. 2003. Using Focus Groups in Research. London: Continuum Mayor K, Tol RSJ. 2007. The impact of the UK aviation tax on carbon dioxide emissions and visitor numbers, Transport Policy 14 (6): 507-513.

Morgan DL. 1997a. Focus Groups as Qualitative Research. London: Sage.

Morgan DL. 1997b. Planning focus groups. London: Sage. 
Office of Fair Trading. 2007. OFT takes action against 13 airlines over misleading holiday pricing. Press release 9-8-2007. [http://www.oft.gov.uk/news/press/2007/118-07, accessed 21-02-2008].

Owen B, Lee D. 2006. Allocation of international aviation emissions from scheduled air traffic - future cases, 2005-2050 (Report 3). Manchester Metropolitan University Centre for Air Transport and the Environment, Final report to Department for Environment, Food and Rural Affairs.

Powell RA, Single HM, Lloyd KR. 1996. Focus groups in mental health research: enhancing the validity of user and provider questionnaires, International Journal of Social Psychology 42 (3): 193-206.

Royal Commission on Environmental Pollution. 2002. The Environmental Effects of Civil Aircraft in Flight, Special Report of the Royal Commission on Environmental Pollution.

[http://www.rcep.org.uk/aviation.htm - accessed 21-02-2008]

Ryley TJ, Davison LJ. 2008. A segmentation analysis of air travel attitudes and behaviour in the East Midlands. Paper presented at Universities Transport Studies Group 40 ${ }^{\text {th }}$ Annual Conference, Portsmouth $3^{\text {rd }}-5^{\text {th }}$ January 2008.

Ryley TJ, Davison LJ, Bristow AL. 2007. Public Engagement on Aviation Taxes. Final Report. Report for the Sustainable Development Commission, 
September 2007. [http://www.sd-commission.org.uk/publications.php?id=600, accessed 21-02-2008].

Stern N, Peters S, Bakhshi V, Bowen A, Cameron C, Catovsky S, Crane D, Cruickshank S, Dietz S, Edmonson N, Garbett S-L, Hamid L, Hoffman G, Ingram D, Jones B, Patmore N, Radcliffe H, Sathiyarajah R, Stock M, Taylor C, Vernon T, Wanjie H, Zenghelis D. 2006. Stern Review on the Economics of Climate Change, HM Treasury, 30 October 2006 [http://www.hm-treasury.gov.uk/independent_reviews/stern_review_economic s_climate_change/sternreview_index.cfm, accessed 21-02-2008].

Tol R S J. 2006. The Stern Review of the economics of climate change: a comment [http://www.fnu.zmaw.de/fileadmin/fnu-files/reports/sternreview.pdf, accessed 15-04-08].

World Commission on Environment and Development. 1987. Our Common Future (Bruntland Report).

York Aviation. 2004. The social and economic aspects of airport in Europe. Airports Council International Europe.

[http://www.yorkaviation.co.uk/Downloads, accessed 21-02-2008]. 
Figure 1. Questionnaire responses as to which measures should be developed to reduce carbon emissions from aircraft, in order of popularity

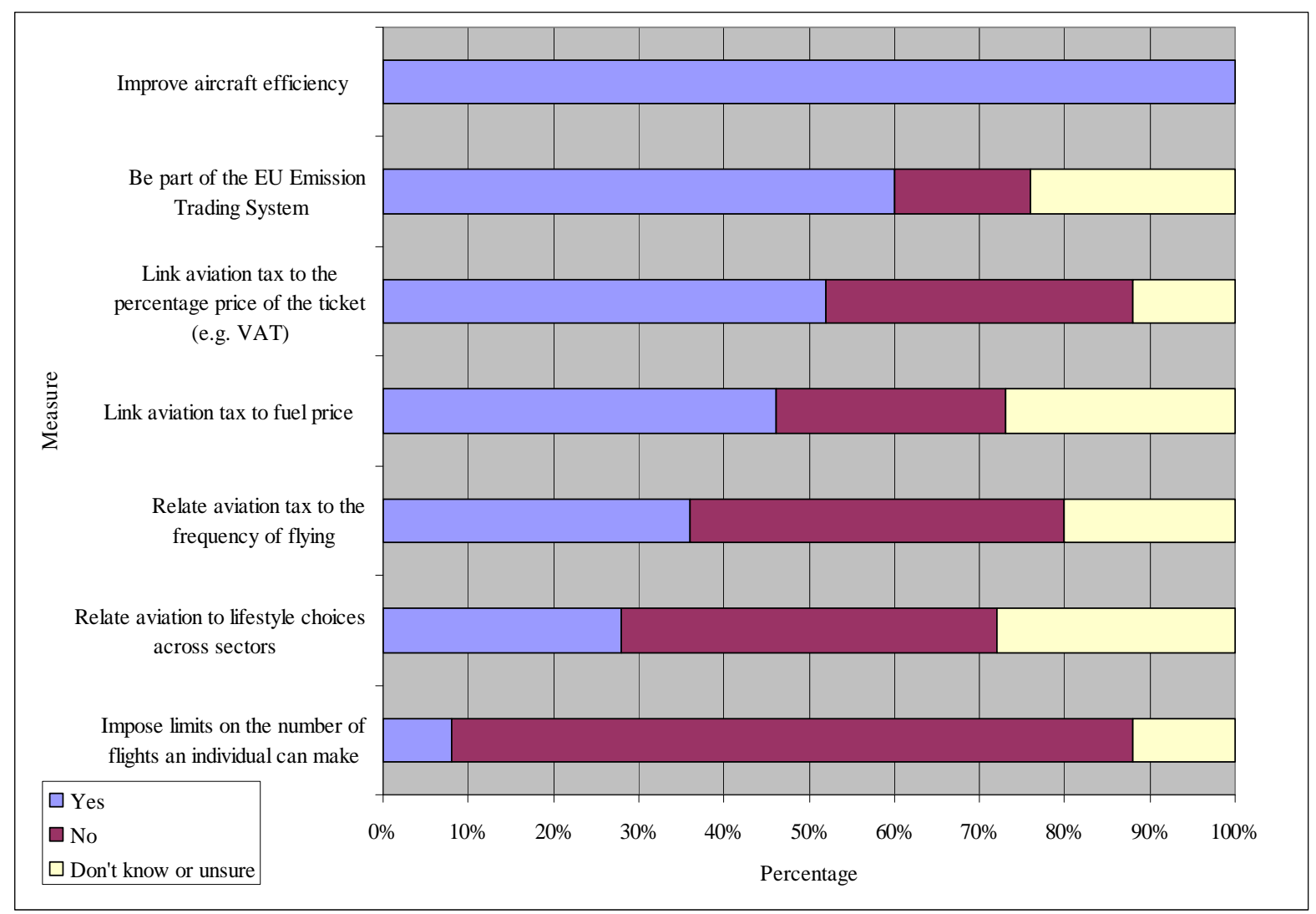

Note: 25 focus group participants filled in this question 
Table 1. The age and status of focus group respondents

\section{AGE}

18-24

25-34

$35-44$

6

$45-54$

5

$55-59$

65-74

1

75 and over

2

TOTAL

\section{STATUS}

Employed full time

Employed part time

4

Looking after home or family

2

Permanently retired from work

Unemployed and seeking work

In education

Unable to work: short-term illness or injury 
Table 2. Questionnaire responses as to what additional money raised from increased aviation tax should go towards?

Yes No $\quad \begin{aligned} & \text { Don't know } \\ & \text { or unsure }\end{aligned}$

Carbon reduction projects

(short-term) to reduce the

environmental impacts of

aircraft, either in the United

Kingdom or abroad

Planting trees

Improving environmentally

$9 \quad 8 \quad 10$

degraded areas

'Green' energy (e.g. wind farms,

solar panels, energy efficient light

$\begin{array}{lll}7 & 13 & 7\end{array}$

bulbs)

Carbon adaptation measures

Sustainable tourism

$21 \quad 4 \quad 2$

Promote drought resistant crops

$\begin{array}{lll}3 & 17 & 7\end{array}$

$\begin{array}{lll}5 & 15 & 7\end{array}$

Environmental measures, not necessarily carbon reducing

Protecting nature and habitats

$7 \quad 4$

Carbon reduction projects (long-

term) to reduce the

environmental impacts of

aircraft, either in the United

Kingdom or abroad

Improving aircraft and aviation

20

$4 \quad 3$

technology

Aviation research

Investment in United Kingdom

14
18

$7 \quad 6$

transport infrastructure

Note: participants could not select more than five aspects in the 'Yes' category 